\title{
THE IMPLEMENTATION OF DIRECT LEARNING MODEL BY USING PROPS BEADS AT THE MATERIAL OPERATIONS IN ADDITION AND SUBTRACTION OF INTEGERS AT THE IVA CLASS IN SD NEGERI 002 TUALANG
}

\author{
ELITA
}

Volume 2 Nomor 1

JIPS ISSN: 2579-5449

\begin{abstract}
Mathematics is a very important lesson so that math needs to be given to all learners starting from elementary school. It aims to equip learners with the ability to think logically, analytically, systematically, critically and creatively as well as the ability to work together. Competence is required for learners have the ability to obtain, manage and utilize information. In line with one of the goals of mathematics in the Education Unit Level Curriculum (SBC) that have properties appreciate the usefulness of mathematics in life is curiosity, concern and interest in studying mathematics, as well as resilient and confident in solving problems.

The researchers interested in improving the learning process in order to achieve maximum mathematics learning results with the application of direct learning models that use beads props in the material of addition operation and reduction of integers in class IVA SD Negeri 002 Tualang, the researcher hopes that it can improve student learning outcomes Better. Based on the background stated above, the authors formulate the problem that is: does the application of direct learning model by using beads props can improve mathematics learning outcomes in the material of addition operation

002 Tualang in the even semester of the school year $2014 / 2015$ ?

This research took place at SD Negeri 002 Tualang. Implemented in the second semester of the school year 2014/2015. This form of research is collaborative classroom action research. Classroom action research aims to improve or improve the quality of classroom teaching practice (Arikunto et al, 2006). Collaborative classroom action research on this research was carried out by researchers with grade IVA teacher SD Negeri 002 Tualang in a team that simultaneously with the aim of improving the practice of learning. Team relationships are partnerships, so that the teacher's position with the rest of the team is the same to think about the issues to be studied in classroom action research.

Based on the results of research and discussion is a fact that the Application of Learning Model Directly on material Operation Count Integer can improve learning outcomes math class student IVA Elementary School 002 Tualang in the second semester of the school year 2014/2015, especially on the subject matter surgery Calculate the integers of the lesson year 2008/2009.
\end{abstract} and reduction of integers in class IVA SD Negeri

\footnotetext{
PENERAPAN MODEL PEMBELAJARAN LANGSUNG YANG MENGGUNAKAN ALAT PERAGA MANIK-MANIK PADA MATERI OPERASI PENJUMLAHAN DAN PENGURANGAN BILANGAN BULAT DI KELAS IVA SD NEGERI 002 TUALANG
} 


\section{ABSTRAK}

Matematika merupakan pelajaran yang sangat penting sehingga matematika perlu diberikan kepada semua peserta didik dimulai dari sekolah dasar. Hal ini bertujuanuntuk membekali peserta didik dengan kemampuan berpikir logis, analitis, sistematis, kritis dan kreatif serta kemampuan bekerja sama. Kompetensi tersebut diperlukan agar peserta didik memiliki kemampuan memperoleh, mengelola dan memanfaatkan informasi. Sejalan dengan salah satu tujuan matematika dalam Kurikulum Tingkat Satuan Pendidikan (KTSP) yaitu memiliki sifat menghargai kegunaan matematika dalam kehidupan yaitu memiliki rasa ingin tahu, perhatian dan minat dalam mempelajari matematika, serta ulet dan percaya diri dalam pemecahan masalah.

Untuk itu peneliti tertarik melakukan perbaikan proses pembelajaran agar dapat mencapai hasil belajar matematika yang maksimal dengan penerapan model pembelajaran langsung yang menggunakan alat peraga manikmanik pada materi operasi penjumlahan dan pengurangan bilangan bulat di kelas IVA SD Negeri 002 Tualang dengan harapan dapat meningkatkan hasil belajar siswa dengan lebih baik. Berdasarkan latar belakang yang dikemukakan di atas maka penulis merumuskan masalah yaitu: Apakah penerapan model pembelajaran langsung dengan menggunakan alat peraga manik-manik dapat meningkatkan

\section{Kata Kunci : alat peraga manik-manik}

\section{PENDAHULUAN}

Latar Belakang, matematika merupakan ilmu yang mendasari perkembangan teknologi modern dan mempunyai peran penting dalam berbagai disiplin ilmu serta mengembangkan daya pikir manusia. Matematika membekali siswa untuk mempunyai kemampuan berpikir logis, analitis, sistematis, kritis, kreatif serta kemampuan bekerjasama. Oleh sebab itu, pelajaran matematika merupakan pelajaran yang sangat penting dalam berbagai situasi baik dalam jenjang pendidikan maupun dalam kehidupan sehari-hari sehingga dapat menjadikan siswa mempunyai kemampuan berfikir kritis dan kerjasama yang baik. hasil belajar matematika pada materi operasi penjumlahan dan pengurangan bilangan bulat di kelas IVA SD Negeri 002 Tualang pada semester genap tahun pelajaran 2014/2015?

Penelitian ini bertempat di SD Negeri 002 Tualang. Dilaksanakan pada semester genap tahun pelajaran 2014/2015. Bentuk penelitian ini adalah penelitian tindakan kelas kolaboratif. Penelitian tindakan kelas bertujuan untuk memperbaiki atau meningkatkan mutu praktek pembelajaran dikelasnya (Arikunto dkk, 2006). Penelitian tindakan kelas kolaboratif pada penelitian ini dilakukan oleh peneliti dengan guru kelas IVA SD Negeri 002 Tualang dalam satu tim yang serentak dengan tujuan meningkatkan praktek pembelajaran. Hubungan dalam tim bersifat kemitraan, sehingga kedudukan guru dengan anggota tim yang lain sama untuk memikirkan persoalan-persoalan yang akan diteliti dalam penelitian tindakan kelas.

Berdasarkan hasil penelitian dan pembahasan diperoleh fakta bahwa Penerapan Model Pembelajaran Langsung pada materi Operasi Hitung Bilangan Bulat dapat meningkatkan hasil belajar matematika siswa kelas IVA SD Negeri 002 Tualang pada semester genap tahun pelajaran 2014 / 2015 SD Negeri 002 Tualang, terutama pada materi pokok operasi hitung bilangan bulat tahun pelajaran 2008/ 2009.

Matematika merupakan pelajaran yang sangat penting sehingga matematika perlu diberikan kepada semua peserta didik dimulai dari sekolah dasar. Hal ini bertujuan untuk membekali peserta didik dengan kemampuan berpikir logis, analitis, sistematis, kritis dan kreatif serta kemampuan bekerja sama. Kompetensi tersebut diperlukan agar peserta didik memiliki kemampuan memperoleh, mengelola dan memanfaatkan informasi. Sejalan dengan salah satu tujuan matematika dalam Kurikulum Tingkat Satuan Pendidikan (KTSP) yaitu memiliki sifat menghargai kegunaan matematika dalam kehidupan yaitu memiliki rasa 
ingin tahu, perhatian dan minat dalam mempelajari matematika, serta ulet dan percaya diri dalam pemecahan masalah (Depdiknas, 2006)

Keberhasilan siswa belajar sangat tergantung pada proses pembelajaran matematika itu sendiri. Proses pembelajaran matematika tidak lepas dari kemampuan guru dalam menguasai konsep dan terampil menerapkan metode pembelajaran yang tepat. Dengan kemampuan ini diharapkan guru dapat menciptakan proses pembelajaran yang menyenangkan dan mudah dipahami oleh siswa. Dengan pemahaman konsep awal yang baik akan memudahkan siswa untuk memahami konsep selanjutnya.

Dari pengamatan penulis di kelas IVA SD Negeri 002 Tualang, masih terlihat bahwa banyak siswa yang kurang memahami konsep dasar dan cenderung menghapal contoh saja. Hal ini tampak dalam penyelesaian soal, saat di sekolah atau materi pembelajaran baru dijelaskan siswa dapat mengerjakan dengan baik, tetapi apabila siswa mengerjakan di rumah atau pada saat ulangan yang waktunya berjauhan dengan waktu pemberian materi pembelajaran, hasil nilai ulangan harian siswa kurang baik karena cenderung asal jawab. Keadaan seperti ini menyebabkan pencapaian hasil belajar siswa kurang memuaskan.

Fakta yang ditemukan di SD Negeri 002 Tualang khususnya di kelas IVA pada materi sebelum dilakukan tindakan yaitu pada semester ganjil tahun pelajaran 2014/2015 masih banyak siswa yang belum mencapai Kriteria Ketuntasan Minimal (KKM) yang sudah ditentukan sekolah yaitu 60 seperti ditunjukkan pada tabel berikut ini.

Berdasarkan kondisi pembelajaran yang diuraikan di atas, maka guru perlu memahami bahwa pola berpikir siswa diusia sekolah dasar bergerak dari hal-hal yang bersifat kongkrit ke hal-hal yang bersifat semi konkrit sehingga siswa memiliki pemahaman yang cukup terhadap suatu konsep. Usaha guru untuk meningkatkan hasil belajar siswa dalam pembelajaran matematika materi sebelumnya hanya sebatas pemberian latihan, penyelesaian soal, remedial dan pengayaan. Guru perlu memikirkan cara-cara penyampaian materi pelajaran secara efektif agar mudah diterima dan melibatkan siswa secara aktif sehingga suasana belajar menjadi menyenangkan dan bermakna yaitu dengan menggunakan alat peraga dan model pembelajaran langsung yang berakibat nilai hasil belajar siswa meningkat.

Dengan menggunakan alat peraga diharapkan penanaman konsep dengan eksperimen pada materi operasi penjumlahan dan pengurangan bilangan bulat di kelas IVA SD Negeri 002 Tualang lebih mudah dipahami siswa, karena siswa tidak hanya mendengarkan konsep saja tetapi terlibat langsung. Dalam pembelajaran langsung ini guru bersama siswa melakukan operasi penjumlahan dan pengurangan bilangan bulat dengan cara mendemonstrasikan operasi tersebut melalui alat peraga manik-manik. Dengan menggunakan alat peraga ini guru dapat menciptakan suasana belajar yang menyenangkan karena siswa terlibat aktif sehingga siswa termotivasi untuk belajar dan dapat meningkatkan hasil belajar siswa.

Untuk itu peneliti tertarik melakukan perbaikan proses pembelajaran agar dapat mencapai hasil belajar matematika yang maksimal dengan penerapan model pembelajaran langsung yang menggunakan alat peraga manikmanik pada materi operasi penjumlahan dan pengurangan bilangan bulat di kelas IVA SD Negeri 002 Tualang dengan harapan dapat meningkatkan hasil belajar siswa dengan lebih baik.

Berdasarkan latar belakang yang dikemukakan di atas maka penulis merumuskan masalah yaitu: Apakah penerapan model pembelajaran langsung dengan menggunakan alat peraga manik-manik dapat meningkatkan hasil belajar matematika pada materi operasi penjumlahan dan pengurangan bilangan bulat di kelas IVA SD Negeri 002 Tualang pada semester genap tahun pelajaran 2014/2015?

Penelitian ini bertujuan untuk meningkatkan hasil belajar matematika siswa melalui penerapan model pembelajaran langsung dengan menggunakan alat peraga manik-manik pada materi operasi penjumlahan dan pengurangan bilangan bulat di kelas IVA SD Negeri 002 Tualang semester genap tahun pelajaran 2014/2015. 


\section{METODE PENELITIAN}

Penelitian ini bertempat di SD Negeri 002 Tualang. Dilaksanakan pada semester genap tahun pelajaran 2014/2015.

Bentuk penelitian ini adalah penelitian tindakan kelas kolaboratif. Penelitian tindakan kelas bertujuan untuk memperbaiki atau meningkatkan mutu praktek pembelajaran dikelasnya (Arikunto dkk, 2006). Penelitian tindakan kelas kolaboratif pada penelitian ini dilakukan oleh peneliti dengan guru kelas IVA SD Negeri 002 Tualang dalam satu tim yang serentak dengan tujuan meningkatkan praktek pembelajaran. Hubungan dalam tim bersifat kemitraan, sehingga kedudukan guru dengan anggota tim yang lain sama untuk memikirkan persoalan-persoalan yang akan diteliti dalam penelitian tindakan kelas.

Dalam hal ini peneliti berperan sebagai guru sedangkan guru kelas IVA berperan sebagai pengamat selama proses pembelajaran. Tindakan yang akan dilakukan adalah penerapan model pembelajaran langsung dengan menggunakan alat peraga manik-manik untuk meningkatkan hasil belajar matematika siswa kelas IVA SD Negeri 002 Tualang.

Dalam penelitian ini dilaksanakan sebanyak dua siklus yaitu siklus I dan siklus II. Siklus pertama dilakukan mulai dari pertemuan pertama sampai pertemuan ketiga, pada pertemuan keempat dilakukan ulangan harian I. Siklus kedua dilaksanakan dari pertemuan kelima sampai pertemuan ketujuh, sedangkan pada pertemuan ke delapan dilakukan ulangan harian II. Selanjutnya masing-masing komponen pada setiap siklus dalam penelitian ini sebagai berikut

1. Perencanaan

Menyusun silabus, rencana pelaksanaan pembelajaran, lembar kerja siswa, mempersiapkan tes hasil belajar dan lembar pengamatan.

2. Pelaksanaan Tindakan

Pelaksanaan tindakan merupakan implementasi dari perencanaan. Kegiatan yang dilakukan oleh guru atau peneliti adalah dalam upaya memperbaiki atau meningkatkan mutu pembelajaran kearah yang diinginkan. Pelaksanaan tindakan dilakukan pada proses pembelajaran secara terstruktur sesuai dengan Rencana Pelaksanaan Pembelajaran dan memberikan LKS dengan menerapkan pembelajaran langsung dengan menggunakan alat peraga manik-manik. Selama proses pembelajaran siswa bekerja berpasangan dengan teman sebangkunya/ berpasangan sesuai pembelajaran yang diterapkan.

3. Pengamatan (Observasi)

Dalam tahap ini yang bertindak sebagai pengamat adalah guru. Pengamatan dilakukan terhadap aktivitas, interaksi dan kemajuan belajar siswa selama pembelajaran berlangsung. Pengamatan atau observasi dilakukan bersamaan dengan pelaksanaan tindakan. Pelaksanaan observasi dilakukan guru yang bekerja sama dengan peneliti dengan menggunakan lembar pengamatan yang disediakan. Pengamatan bertujuan untuk mengamati semua aktivitas guru dan siswa selama proses pembelajaran berlangsung.

4. Refleksi

Refleksi dilakukan setelah tindakan berakhir yang merupakan perenungan bagi guru atau peneliti atas dampak dari proses pembelajaran yang dilakukan. Kegiatan refleksi akan menimbulkan pertanyaan yang bisa dijadikan sebagai acuan keberhasilan misalnya apakah hasil belajar siswa sudah menunjukkan ketuntasan secara individual serta bagaimana aktivitas dan interaksi siswa dalam proses pembelajaran yang dilakukan. Hasil dari refleksi ini dapat dijadikan sebagai langkah untuk merencanakan tindakan baru pada pelaksanaan pembelajaran selanjutnya. Karena penelitian ini terdiri dari dua siklus maka tahap ini bertujuan untuk mengkaji, melihat dan mempertimbangkan atas hasil atau dampak dari tindakan. Kelemahan dan kekurangan pada siklus I akan diperbaiki pada siklus II.

Penelitian ini diadakan di SD Negeri 002 Tualang semester genap tahun pelajaran 2014/2015. Sebagai subjek dalam penelitian ini adalah siswa kelas IV SD Negeri 002 Tualang dengan jumlah 36 orang, yang terdiri dari lakilaki 16 orang dan perempuan 20 orang. Kemampuan siswa pada mata pelajaran matematika khususnya siswa kelas IVA SD Negeri 002 Tualang dikategorikan masih dibawah standar KKM yang ditetapkan sekolah.

Perangkat pembelajaran yang digunakan pada penelitian ini terdiri dari: silabus, rencana pelaksanaan pembelajaran, buku siswa dan LKS.

Silabus disusun berdasarkan prinsip yang berorientasi pada pencapaian kompetensi. Sesuai 
dengan prinsip tersebut maka silabus pelajaran matematika memuat indentitas sekolah, standar kompetensi, kompetensi dasar, materi pokok, kegiatan pembelajaran, indikator, penilaian, alokasi waktu, sumber belajar. Silabus berguna untuk memberikan pedoman bagi guru dalam penyusunan rencana pelaksanaan pembelajaran.

Rencana Pelaksanaan Pembelajaran memuat standar kompetensi, kompetensi dasar, indikator, tujuan pembelajaran, materi ajar, model dan metode pembelajaran, langkahlangkah pembelajaran yang memuat kegiatan awal, kegiatan inti, kegiatan akhir, alat/bahan/sumber belajar, dan penilaian. Bagi guru rencana pelaksanaan pembelajaran dapat digunakan sebagai acuan dalam pelaksanaan pembelajaran.

Pada penelitian ini RPP dipersiapkan sebanyak enam buah masing-masingnya memuat indikator ketercapaian yang dikembangkan dari kompetensi dasar. RPP-1 (lampiran $\mathrm{B}_{1}$ ) memuat dua indikator yaitu operasi penjumlahan bilangan bulat positif dengan bilangan bulat positif dan penjumlahan bilangan bulat negatif dengan bilangan bulat negatif, RPP-2 (lampiran $\mathrm{B}_{2}$ ) penjumlahan bilangan bulat positif dengan bilangan bulat negatif, RPP-3 (lampiran $\mathrm{B}_{3}$ ) memuat indikator mengurangkan bilangan bulat positif dengan bilangan bulat positif, RPP-4 (lampiran $\mathrm{B}_{4}$ ) mengurangkan bilangan bulat negatif dengan bilangan bulat negatif, RPP-5 (lampiran $\mathrm{B}_{5}$ ) mengurangkan bilangan bulat positif dengan bilangan bulat negatif dan sebaliknya, dan RPP-6 (lampiran $\mathrm{B}_{6}$ ) melakukan operasi hitung campuran.

Buku siswa yang digunakan adalah buku sekolah dengan judul Terampil Berhitung Matematika untuk SD kelas IV, karangan Tim Bina Karya Guru terbitan Erlangga tahun terbit 2006. Buku ini sebagai panduan siswa dalam mengerjakan soal-soal latihan, serta panduan guru dalam menyusun soal-soal latihan.

Lembar Kerja Siswa memuat soal-soal latihan yang terdiri dari enam buah yang masingmasing digunakan untuk setiap kali pertemuan. Masing-masing LKS terdiri dari tiga lembar. Lembar kerja siswa memuat kompetensi dasar, indikator, tujuan pembelajaran dan langkahlangkah yang harus dikerjakan dalam menyelesaikan masalah yang dikembangkan dalam membangun pengalamannya serta tugas yang harus dikerjakan. Dalam LKS terdapat Lembar Latihan Terbimbing yang memuat soalsoal yang harus dikerjakan oleh siswa dengan bimbingan guru.

Lembar Latihan Lanjutan dibagikan kepada siswa digunakan dalam proses pembelajaran bertujuan untuk mengecek tingkat pemahaman siswa terhadap materi yang sudah disajikan. Lembar Latihan Lanjutan ini disediakan sebanyak enam buah untuk enam kali pertemuan dan dibagikan kepada setiap siswa. Lembar Latihan Lanjutan ini tidak dinilai melainkan diberi penguatan bagi yang berhasil dan bimbingan bagi yang mengalami kesulitan.

Instrumen pengumpul data yang diperlukan dalam penelitian ini adalah lembar pengamatan dan tes hasil belajar. Lembar pengamatan yang digunakan adalah lembar pengamatan terbuka yang digunakan untuk memperoleh data tentang aktivitas guru dan siswa selama proses pembelajaran. Lembar pengamatan (lampiran E) dibuat berdasarkan fase-fase pembelajaran langsung. Tes hasil belajar mengacu pada kisi-kisi soal (lampiran F) yang telah dibuat dan digunakan untuk memperoleh data setelah berlangsung proses pembelajaran. Tes hasil belajar dilakukan dua kali yaitu Ulangan Harian I (lampiran $\mathrm{G}_{1}$ ) dan Ulangan Harian II (lampiran $\mathrm{G}_{2}$ ).

Data dalam penelitian ini dikumpulkan menggunakan lembar pengamatan dan tes hasil belajar matematika. Pengamatan dilakukan terhadap aktivitas guru dan siswa selama proses pembelajaran untuk setiap pertemuan dengan mengisi lembar pengamatan yang sudah disediakan pada tiap pertemuan.

Data tentang hasil belajar matematika siswa dilakukan dengan melakukan ulangan harian pada materi operasi penjumlahan dan pengurangan bilangan bulat. Ulangan harian dilakukan sebanyak dua kali yaitu Ulangan Harian I dan Ulangan Harian II. Soal-soal pada ulangan harian dibuat berdasarkan indikator yang ingin dicapai pada materi operasi penjumlahan dan pengurangan bilangan bulat.

Data yang sudah diperoleh melalui lembar pengamatan kemudian dianalisis. Analisis data yang dilakukan adalah analisis deskriptif. Analisis deskiptif bertujuan untuk menggambarkan data tentang aktivitas guru dan siswa selama proses pembelajaran. 


\section{HASIL PENELITIAN DAN PEMBAHASAN}

Penerapan model pembelajaran langsung dengan menggunakan media manik-manik pada penelitian ini dilakukan melalui beberapa tahap yaitu:

Pada tahap ini, peneliti mempersiapkan instrumen penelitian yang terdiri dari perangkat pembelajaran dan instrumen pengumpulan data. Perangkat pembelajaran terdiri dari silabus (lampiran A), rencana pelaksanaan pembelajaran (lampiran B), lembar kerja siswa (lampiran C), lembar latihan lanjutan (lampiran D) untuk setiap pertemuan. Kemudian peneliti mempersiapkan media manik-manik, paku kecil dan papan panel untuk guru. Untuk siswa guru mempersiapkan manik-manik sebanyak 10 manik biru dan 10 manik kuning untuk setiap meja yang akan digunakan oleh dua orang siswa untuk melakukan pembelajaran.

Instrumen pengumpulan data yang digunakan adalah lembar pengamatan (lampiran E) dan perangkat tes hasil belajar matematika ulangan harian I dan ulangan harian II yang terdiri dari kisi-kisi penulisan soal $(\mathrm{F})$, soal ulangan $(G)$ dan alternatif jawaban serta bobot dari setiap soal $(\mathrm{H})$. Skor nilai sebelum tindakan siswa diambil dari nilai ulangan pada materi pembelajaran menentukan Keliling dan Luas Bangun Datar.

Pelaksanaan pembelajaran dengan penerapan model pembelajaran langsung dengan menggunakan media manik-manik, dilakukan sebanyak 8 kali pertemuan dengan rincian, 6 kali pertemuan menyajikan materi dan 2 kali pertemuan mengadakan tes (UH I dan UH II). Selanjutnya proses pembelajaran selama penelitian diuraikan sebagai berikut:

Siklus Pertama

Untuk siklus pertama dilakukan sebanyak tiga kali pertemuan dengan satu kali tes (ulangan harian I).

a. Pertemuan Pertama ( Senin, 30 Maret 20014)

Pada pertemuan ini kegiatan pembelajaran membahas tentang penjumlahan bilangan bulat positif dengan bilangan bulat positif dan penjumlahan bilangan bulat negatif dengan bilangan bulat negatif yang berpedoman pada RPP 1 (lampiran $\mathrm{B}_{1}$ ), lembar kerja siswa 1 (lampiran $\mathrm{C}_{1}$ ) dan lembar latihan lanjutan 1 (lampiran $\mathrm{D}_{1}$ ).

Proses pembelajaran diawali dengan membuka pelajaran dan menyampaikan tujuan pembelajaran yang ingin dicapai. Kemudian peneliti memberikan motivasi kepada siswa dengan mengaitkan materi dalam kehidupan sehari-hari yaitu menghitung kenaikan suhu yang terjadi pada siang hari.

Pada kegiatan inti, peneliti menjelaskan prinsip kerja alat peraga manik-manik untuk menentukan bilangan bernilai nol. Pada tahap ini siswa banyak yang bingung dengan bilangan netral (nol). Kemudian peneliti mendemonstrasikan cara penjumlahan bilangan bulat positif dengan bilangan bulat positif dan penjumlahan bilangan negatif dengan bilangan bulat negatif menggunakan alat peraga manikmanik.

Dalam mendemonstrasikan penjumlahan bilangan bulat positif dengan bilangan bulat positif dan penjumlahan bilangan bulat negatif dengan bilangan bulat negatif siswa tidak banyak mengalami kesulitan apalagi dengan menggunakan alat peraga manik-manik. Setelah itu peneliti membagikan manik-manik dan LKS pada siswa. LKS dikerjakan oleh masing-masing siswa dengan menggunakan manik-manik yang telah dibagikan oleh peneliti pada tiap meja dan dipakai secara berpasangan. Peneliti membimbing siswa menyelesaikan LKS dengan cara berkeliling. Peneliti memeriksa LKS dan memberi umpan balik dengan tanya jawab mengenai operasi penjumlahan bilangan bulat positif dengan positif dan penjumlahan bilangan bulat negatif dengan negatif. Kemudian peneliti memberikan lembar latihan lanjutan pada siswa untuk dikerjakan siswa secara individu.

Peneliti mengakhiri pembelajaran pada pertemuan ini dengan memberi penilaian dan penguatan atas hasil keja siswa. Kemudian peneliti bersama siswa menyimpulkan materi operasi penjumlahan bilangan bulat positif dengan bilangan bulat positif dan penjumlahan bilangan bulat negatif dengan bilangan bulat negatif yang baru dipelajari. Siswa

menuliskan kesimpulan dan PR yang diberikan peneliti. Kesimpulan yang didapatkan siswa pada pertemuan pertama ini adalah jika bilangan bulat positif dijumlahkan dengan bilangan bulat positif maka hasilnya adalah bilangan bulat positif dan jika bilangan bulat negatif dijumlahkan dengan bilangan bulat negatif maka hasilnya adalah bilanganbulat negatif. 
Pada pertemuan ini, aktivitas guru dan siswa berdasarkan lembar pengamatan pertama (lampiran $\mathrm{E}_{1}$ ) tidak mengalami kesulitan dalam operasi penjumlahan bilangan bulat positif dengan bilangan bulat positif dan penjumlahan bilangan bulat negatif dengan bilangan bulat negatif. Namun siswa mengalami kesulitan dalam memahami prinsip kerja manik-manik terutama dalam memahami konsep bilangan netral atau nol dalam prinsip kerja manik-manik sehingga peneliti harus berulang kali menjelaskan mengenai bilangan netral atau bilangan yang bernilai nol. Peneliti telah berusaha agar siswa dapat memahami prinsip kerja manik-manik terutama tentang bilangan netral atau nol dalam penggunaan alat peraga manik-manik.

b. Pertemuan Kedua ( Selasa, 31 Maret 2014)

Pada pertemuan kedua ini kegiatan pembelajaran membahas tentang operasi penjumlahan bilangan bulat positif dengan bilangan bulat negatif yang berpedoman pada RPP 2 (lampiran $\mathrm{B}_{2}$ ), lembar kerja siswa 2 (lampiran $\mathrm{C}_{2}$ ) dan lembar latihan lanjutan 2 (lampiran $\mathrm{D}_{2}$ ).

Proses pembelajaran diawali peneliti dengan tanya jawab mengenai pelajaran lalu yang belum dipahami siswa, dilanjutkan dengan menyampaikan tujuan pembelajaran yang ingin dicapai dan menjelaskan kegiatan yang akan dilakukan. Kemudian peneliti mempersiapkan alat dan bahan yang diperlukan dalam pembelajaran seperti manik-manik dan papan panel yang dibutuhkan

Pada kegiatan inti, peneliti menjelaskan cara mengerjakan penjumlahan bilangan bulat positif dengan bilangan bulat negatif yang hasilnya positif dengan menggunakan manikmanik Kemudian peneliti mendemonstrasikan cara penjumlahan bilangan bulat positif dengan bilangan bulat negatif yang hasilnya positif. Setelah itu peneliti juga menjelaskan dan mendemonstrasikan penjumlahan bilangan bulat positif dengan bilangan bulat negatif yang hasilnya negatif menggunakan alat peraga manik-manik.

Dalam mendemonstrasikan penjumlahan bilangan bulat positif dengan bilangan bulat negatif baik yang hasilnya positif maupun yang hasilnya negatif, siswa mengalami kesulitan yang apalagi dengan menggunakan alat peraga manikmanik. Peneliti tidak lupa menanyakan pada siswa jika masih ada bagian yang belum jelas dan mengerti. Setelah itu peneliti membagikan manik-manik dan LKS pada siswa. LKS dikerjakan oleh siswa dengan menggunakan manik-manik yang telah dibagikan oleh peneliti pada tiap meja dan dipakai secara berpasangan. Peneliti membimbing siswa menyelesaikan LKS dengan cara berkeliling. Peneliti memeriksa LKS dan memberi umpan balik dengan tanya jawab mengenai operasi hitung penjumlahan bilangan bulat positif dengan bilangan bulat negatif baik yang hasilnya positif maupun yang hasilnya negatif. Kemudian peneliti memberikan lembar latihan lanjutan pada siswa untuk dikerjakan siswa secara individu.

Peneliti mengakhiri pembelajaran pada pertemuan ini dengan memberi penilaian dan penguatan atas hasil keja siswa. Kemudian peneliti bersama siswa menyimpulkan materi operasi penjumlahan bilangan bulat positif dengan bilangan bulat negatif yang hasilnya positif dan hasilnya negatif yang baru dipelajari. Siswa menuliskan kesimpulan materi yaitu jika bilangan bulat positif lebih besar di jumlahkan dengan bilangan bulat negatif yang lebih kecil nilainya maka hasilnya adalah bilangan bulat positif dan jika bilangan bulat negatif lebih besar dijumlahkan bilangan bulat positif yang nilainya lebih kecil maka hasilnya adalah bilangan bulat negatif. Kemudian siswa menuliskan PR yang diberikan peneliti.

Berdasarkan lembar pengamatan 2 (lampiran $\mathrm{E}_{2}$ ) pada pertemuan ini, aktivitas guru sudah terlaksana dengan baik. Sedangkan pada lembar aktivitas siswa, terdapat kelemahan yaitu dalam pengerjaan LKS 2 ada siswa yang bertanya pada teman yang di kiri dan di kanannya sehingga mengganggu konsentrasi temannya yang lain. Sedangkan pada kegiatan lainnya aktivitas siswa sudah berjalan dengan baik begitu juga dengan pengerjaan Lembar Latihan Lanjutan.

c. Pertemuan Ketiga ( Rabu, 1 April 2014)

Pada pertemuan ketiga ini kegiatan pembelajaran membahas tentang operasi pengurangan bilangan bulat positif dengan bilangan bulat positif yang berpedoman pada RPP 3 (lampiran $\mathrm{B}_{3}$ ), lembar kerja siswa 3 (lampiran $\mathrm{C}_{3}$ ) dan lembar latihan lanjutan 3 (lampiran $\mathrm{D}_{3}$ ).

Pada pertemuan ini proses pembelajaran diawali peneliti dengan tanya jawab mengenai pelajaran lalu yang belum dipahami siswa, dilanjutkan dengan menyampaikan tujuan pembelajaran yang ingin dicapai tentang operasi pengurangan bilangan bulat positif dengan 
bilangan bulat positif dan menjelaskan kegiatan yang akan dilakukan. Kemudian peneliti memotivasi siswa dengan mengaitkan materi dalam kehidupan sehari-hari. Contoh: mengurangkan apel dalam keranjang dengan apel yang busuk dalam keranjang itu.

Selanjutnya pada kegiatan inti, peneliti menjelaskan prinsip kerja kerja alat peraga manik-manik pada operasi pengurangan bilangan bulat. Kemudian peneliti mendemonstrasikan cara pengurangan bilangan bulat positif dengan bilangan bulat positif yang hasilnya positif yang hasilnya positif dengan menggunakan manikmanik. Siswa mengikuti petunjuk guru dan bekerja berpasangan.

Setelah itu peneliti juga menjelaskan dan mendemonstrasikan pengurangan bilangan bulat positif dengan bilangan bulat positif yang hasilnya negatif menggunakan alat peraga manik-manik.

Dalam mendemonstrasikan pengurangan bilangan bulat positif dengan bilangan bulat positif baik yang hasilnya positif maupun yang hasilnya negatif, peneliti menyuruh beberapa siswa secara bergiliran maju ke depan kelas untuk mengerjakan soal-soal yang diberikan guru dengan menggunakan manik-manik yang tersedia dengan tujuan agar siswa lebih mengerti. Setelah itu peneliti membagikan manik-manik dan LKS pada siswa. Siswa mengerjakan LKS mengikuti petunjuk yang telah didemonstrasikan dengan bimbingan peneliti. Peneliti membimbing siswa menyelesaikan LKS dengan cara berkeliling. Peneliti memeriksa LKS dan memberi umpan balik dengan tanya jawab mengenai operasi hitung pengurangan bilangan bulat positif dengan bilangan bulat positif baik yang hasilnya positif maupun yang hasilnya negatif. Kemudian peneliti memberikan lembar latihan lanjutan pada siswa untuk dikerjakan siswa secara individu.

Peneliti mengakhiri pembelajaran pada pertemuan ini dengan memberi penilaian dan penguatan atas hasil keja siswa. Kemudian peneliti bersama siswa menyimpulkan materi operasi pengurangan bilangan bulat positif dengan bilangan bulat positif yang hasilnya positif dan hasilnya negatif yang baru dipelajari. Siswa menuliskan kesimpulan materi tersebut dan menuliskan PR yang diberikan peneliti.

Berdasarkan lembar pengamatan 3 (lampiran $\mathrm{E}_{3}$ ) pada pertemuan ketiga ini, aktivitas guru dan aktivitas siswa sudah terlaksana dengan baik sesuai dengan perencanaan pada RPP 3. Sehingga peneliti dapat menyimpulkan bahwa proses pembelajaran pada pertemuan ketiga ini sudah lebih baik daripada dua pertemuan selanjutnya.

d. Pertemuan Keempat ( Senin, 6 April 2014)

Pada pertemuan keempat, peneliti mengadakan ulangan harian I. Sebelum ulangan, peneliti menanyakan pekerjaan rumah yang belum dimengerti siswa, kemudian melakukan ulangan harian I yang dilaksanakan 2 x 35 menit. Soal ulangan harian I disediakan oleh peneliti yaitu lampiran $\mathrm{G}_{1}$.

Refleksi siklus pertama:

Dalam pelaksanaan siklus I dari pertemuan 1 sampai pertemuan 3 peneliti dapat menyimpulkan masih ada beberapa kekurangan yang dilakukan guru dan siswa yaitu;

a. Bimbingan dari peneliti terhadap siswa yang lemah masih kurang optimal.

b. Pada pengerjaan lembar kerja siswa masih ada siswa yang mengalami kesulitan sehingga waktu mengerjakan LKS-nya siswa masih ada yang bekerja tidak mandiri yang ditunjukkan dengan adanya siswa yang melihat pekerjaan teman di kiri dan di kanannya.

Rencana yang dilakukan peneliti untuk memperbaiki tindakan ini adalah;

1. Memantau dan membimbing siswa secara optimal terutama terhadap siswa yang lemah dengan cara memberikan bimbingan khusus kepada siswa yang lemah.

2. Peneliti lebih cermat memperhatikan kegiatan siswa agar terfokus dalam mengerjakan LKS-nya dengan baik.

\section{Siklus Kedua:}

Untuk siklus kedua dilakukan sebanyak tiga kali petemuan dengan satu kali tes (ulangan harian II). Pada siklus kedua ini peneliti masih tetap menerapkan tahap-tahap pembelajaran pada siklus pertama. Selanjutnya peneliti berusaha melakukan perbaikan-perbaikan yang telah direncanakan sebagai refleksi dari siklus pertama.

Untuk siklus kedua siswa mengalami beberapa kesulitan karena tingkat kesulitan materi yang disampaikan pada siklus kedua lebih tinggi kerumitannya dibandingkan dengan materi yang disampaikan pada siklus pertama. Siswa tampak lebih berani mengungkapkan ide ataupun kesulitan yang mereka hadapi mengenai pembelajaran Dalam hal ini peneliti berusaha selalu membimbing siswa dengan cara 
mendemonstrasikan dan menjelaskan kembali kepada siswa dengan harapan siswa dapat memahami materi yang dipelajari. Dari refleksi siklus kedua ini peneliti tidak melakukan perencanaan untuk siklus selanjutnya karena pada penelitian ini hanya dilakukan sebanyak dua siklus.

Data yang dianalisis dalam penelitian ini adalah data tentang aktivitas guru dan siswa dalam proses pembelajaran dan ketuntasan hasil belajar matematika.

Untuk mengetahui aktivitas guru dan siswa dilakukan pengamatan terhadap aktivitas guru dan siswa selama proses pembelajaran berlangsung. Berdasarkan pengamatan terhadap aktivitas guru dan siswa maka diperoleh fakta tentang kesesuaian antara aktivitas guru dan siswa dalam proses pembelajaran dengan aktivitas yang dituntut dalam RPP.

Dari hasil analisis data, diperoleh kesimpulan bahwa aktivitas guru dan siswa dalam proses pembelajaran pada pertemuan

\section{KESIMPULAN DAN SARAN}

Berdasarkan hasil penelitian dan pembahasan diperoleh fakta bahwa Penerapan Model Pembelajaran Langsung pada materi Operasi Hitung Bilangan Bulat dapat meningkatkan hasil belajar matematika siswa kelas IVA SD Negeri 002 Tualang pada semester genap tahun pelajaran 2014 / 2015 SD Negeri 002 Tualang, terutama pada materi pokok operasi hitung bilangan bulat tahun pelajaran 2008/ 2009.

Memperhatikan kesimpulan dan pembahasan hasil penelitian di atas maka peneliti menyatakan; 1) Guru dapat menggunakan model pembelajaran langsung sebagai salah satu pembelajaran untuk meningkatkan kualitas pertama belum sepenuhnya sesuai. Hal ini disebabkan karena siswa baru pertama kali belajar dengan menggunakan model pembelajaran ini.

Pertemuan kedua, ketiga, keempat, kelima, keenam dan ketujuh aktivitas guru dan siswa pada lembar pengamatan telah memperlihatkan perubahan yang semakin baik walaupun sampai pada pertemuan terakhir belum seluruhnya seperti yang diharapkan. Artinya setiap kali pertemuan kesesuaian aktivitas guru dan siswa semakin mendekati yang diharapkan dalam pembelajaran. Adanya peningkatan tersebut menunjukkan bahwa terdapat peningkatan kualitas pembelajaran pada setiap peremuan.

Hal di atas menunjukkan bahwa siswa semakin memahami dan mampu melakukan aktivitas pembelajaran sesuai dengan yang ditentukan dalam RPP. Untuk keseluruhan siswa masih perlu waktu yang cukup agar benar-benar mampu mengikuti pembelajaran yang baik.

proses pembelajaran dalam rangka meningkatkan hasil belajar matematika siswa kelas IV SD Negeri 002 Tualang pada materi operasi bilangan bulat. 2) Kepada peneliti yang berminat menindaklanjuti penelitian ini diharapkan untuk mensosialisasikan lembar pengamatan sesuai dengan yang diharapkan dan juga peneliti dapat memilih salah satu alternatif model pembelajaran langsung yang disesuaikan dengan kondisi siswa dan sekolah. 3) Bagi sekolah melalui model pembelajaran ini hendaknya dapat diterapkan di SD Negeri 002 Tualang sehingga dapat meningkatkan mutu pendidikan ke arah yang lebih baik. 


\section{DAFTAR PUSTAKA}

Arikunnto, dkk 2006. Penelitian Tindakan Kelas. Bumi Aksara. Jakarta.

Arsyad, Azhar, 2002. Media Pembelajaran, Rajawali Pers, Jakarta.

Depdiknas, 2006. Pedoman penyusunan KTSP.

Sekolah Dasar.

FKIP. UNRI, 2005. Panduan Penulisan Karya Ilmiah jurusan FMIPA. UNRI. Pekanbaru.

Hakim, T, 2002. Belajar Secara Efektif, Puspa Swara, Jakarta.

Hamalik, O, 2003. Perencanaan Pengajaran Berdasarkan Pendekatan Sistem, Bumi Aksara, Jakarta.

Heleni dan Zulkarnain, 2006. Pembelajaran Matematika I, Cendikia Insani, Pekanbaru.

Kardi dan Nur, 2000. Pengajaran Langsung. UNESA-UNIVERSITI

PRESS.Surabaya.
Moedjiono dan Moh. Dimyati, 2002. Strategi Belajar Mengajar. Jakarta; Depdikbud.

Russefendi,1991. Materi Pokok Pendidikan Matematika 3 PPGM, Yokyakarta.

Rohani, A, 1997. Media Instruksional Edukatif, Rineka Cipta. Jakarta.

Sadiman, Arif, dkk, 1996. Media Pendidikan, Raja Grafindo Persada, Jakarta.

Slameto, 2003. Belajar dan Faktor Faktor yang Mempengaruhinya. Rineka Cipta. Jakarta.

Sudjana, N, 2000. Dasar-dasar Proses Belajar Mengajar. Sinar Baru Algensindo, Bandung.

Sudjana, N, 2004. Dasar-dasar Proses Belajar Mengajar. Remaja Rosdakarya, Bandung.

Subroto, Suryo.1997. Proses Belajar Mengajar.Rineka Cipta. Jakarta 